\title{
K-Ar geochronology on alkaline volcanic rocks, southern Paraná Basin, Uruguay
}

\author{
MuZIO, R. ${ }^{{ }^{*}}$; OLIVERA, L. ${ }^{1}$; PEEL, E. ${ }^{1}$
}

${ }^{1}$ Facultad de Ciencias, Universidad de la República. Iguá 4225, CP 11400 Montevideo, Uruguay.

(*correspondence: rossana@fcien.edu.uy)

The exposed volcanic areas of the Paraná Basin in Uruguay are mainly represented by tholeiitic basalt lava flows and related mafic intrusions, with ages restricted to the lower Cretaceous [1] [2]. Recent studies have shown the occurrence of undersaturated mafic lavas, cross cutting the basaltic pile. They represent the first record of volcanic rocks of alkaline nature for the southernmost portion of the Paraná Basin and for Uruguay, and they were interpreted as three possible volcanic plugs. These porphyritic volcanic rocks correspond to Ne-tephrites, according to the geochemical classification and to their mineralogy composed of olivine (forsterite) and augite phenocrysts in a hypocrystalline groundmass with olivine, augite, plagioclase microlites, nepheline, apatite and opaque minerals, mainly ulvospinel and pyrite [3]. Two samples correspondent to different occurrences have undergone to $\mathrm{K}-\mathrm{Ar}$ (whole rock) geochronology analyses at Actlabs Laboratories (Canada). The ages obtained fall between $63.7 \pm 2.5 \mathrm{Ma}$ and $51.5 \pm 1.7 \mathrm{Ma}$. They represent not only the first record of volcanic rocks of alkaline nature for the Paraná Basin in Uruguay but also the first record of Cenozoic volcanism.

[1] Muzio et al. (2017) J.S.Am. Earth Sci. 77, 92-107 [2] Peate (1997) Geoph.Monograph 100, 217-245 [3] Muzio et al. (2019) Goldschmidt Abstracts. 